\title{
MULTINACIONÁLIS VÁLLALATOK GLOBALIZÁLT ERP-MODELLJEI, FEJLŐDÉSI TENDENCIÁK
}

A cikk nemzetközi cégeknél, illetve multinacionális vállalkozások hazai leányvállalatainál folytatott kutatás és szakértôi megbeszélések alapján az ERP- (Enterprise Resource Planning) rendszerek globális telepítésének IT-struktúráit mutatja be, mely struktúrák a konszernszintú (centralizált) és országspecifikus (lokális) feldolgozások kapcsolatában alakulnak ki. A szerzók célja, hogy az ERP-rendszerek egyre növekvố alkalmazásainak telepítési formáit modellekbe foglalják. A gyakorlati tapasztalatok és szakirodalmi elemzés alapján az ERP globalizálódási folyamat fejlódési irányait is bemutatják.

Kulcsszavak: globalizált ERP, globalizált IT-struktúra, multinacionális vállalkozások rendszerei, vállalatirányítási rendszerek, ERP fejlódési trendek

Internacionális vállalkozások IT-vezetésének egyik célja a konszernhez tartozó országspecifikus ERP-k integrálása a központi irányítási rendszerbe és ezzel az aktuális adatok biztosítása a vezetés részére. Ennek több megvalósítási formája létezik, mint például:

- egy egységes ERP-re való áttérés az összes leányvállalatnál (Kulcsár, 2006),

- a meglévő (országonként egységes, vagy különböző) ERP-rendszerek hálózati összekapcsolása a centralizált feldolgozással (Gronau, 2008),

- a múködés szempontjából meghatározó üzleti folyamatra egységes ERP (pl. vevói kapcsolatok kezelésére egy kiválasztott $\mathrm{CRM}=$ Customer Relationship Management) bevezetése minden leányvállalatnál (Wheatley, 2007a).

Az országszintú feldolgozórendszereket átszervezó, egységesítő folyamatot nevezzük globalizációnak, melynek eredményeként globalizált ERP-struktúrák alakulnak ki. Ezek jellegzetessége, hogy az országspecifikus feldolgozások egyre szorosabban kapcsolódnak a centralizált, konszernszintü rendszerhez. Az ERP globalizációs folyamatot a vállalkozások kihelyezési (off-shoring/ near-shoring) trendjének növekedése is gyorsítja. A Német Statisztikai Hivatal adatai szerint 2001-2006 között a 100 főnél nagyobb német vállalkozások 14\%-a alapí- tott külföldön vállalkozást, melynek logikus következménye, hogy ez párhuzamosan a cég adatfeldolgozó rendszerének kiterjesztését is eredményezi (Höh, 2009).

Munkánkban az ERP globalizálási folyamat jelenlegi helyzetéról és várható irányairól adunk áttekintést, mely eredmények az ELTE-GDF kutatási projekt keretében jöttek létre. A téma aktualitását a nemzetközi vállalkozásoknál tapasztalható egyre erôteljesebb ERP egységesítési folyamat indokolja, melynek célja, hogy a konszernek regionális számítóközpont(ok)ban, a leányvállalati ERP-ket országspecifikus paraméterezéssel, de a központi (centrális) feldolgozórendszer részére on-line elérhetôséggel üzemeltessék.

ERP-rendszerek globalizálódását egy nemzetközi kutatás keretében vizsgáljuk magyar és német egyetemi tanszékek részvételével, a Gábor Dénes Főiskola szakmai irányításával. A kutatási projekt 2009 júliusában indult a Leistritz (Nürnberg) és Schäubli AG. (Bayreuth) cégeknél (Szabó, 2009c). Jelenleg döntően nemzetközi cégek hazai vállalatainál folytatunk interjúkat. A kutatásban részt vevő intézmények: ELTE, GDF, Budapesti Corvinus Egyetem, Debreceni Egyetem, Szegedi Tudományegyetem, Pécsi Tudományegyetem, Szent István Egyetem, Uni. Göttingen, Hochschule Ingolstadt, Uni. Potsdam, melyek saját kutatási eredményeiket külön-külön is publikálják. 
A kutatás első fázisában a globalizációs folyamattal kapcsolatosan négy kérdést fogalmaztunk meg:

a) Milyen modellekbe sorolhatóak az ERP globalizációs folyamatok?

b) Mely területeken (ügyviteli folyamatokban) tapasztalható erốteljes törekvés az internacionális vállalkozáson belül a globalizált ERP kialakítására, illetve milyen mélységú, ,standardizált” ERP létrehozására törekednek a nemzetközi cégek?

c) Mely előnyöket nyújt egy új, globalizált ERP bevezetése?

d) Milyen ERP fejlesztési trendek figyelhetốk meg?

E kérdések megválaszolására a kialakított módszertan alapján az egyes kutatóhelyek (tanszékek) multinacionális cégeknél folytatnak szakmai megbeszéléseket. A 16 nemzetközi cég rendszerstruktúrájának felmérése és elemzése alapján egy „Kutatási Beszámoló” készült, melyben a részt vevố tanszékek az eddigi eredményeket 2010 májusában dokumentálták (ELTE, 2010).

\section{Kutatási módszertan és adatelemzés}

A kutatás módszertani elvei a következók voltak:

- globális vállalatok (15-20 szervezet) CIO-szintú vezetôivel készített mélyinterjú,

- egységes, módszertanilag egyeztetett kérdôív alapján, szóbeli megkérdezés, két kutató részvételével,

- utólagos információkérés, kiegészítés,

- az egyetemi elemzók által feldolgozott interjúk dokumentálása egységes felépítésben (3-6 oldal, cégenként),

- kvalitatív és kvantitatív jellegú összehasonlító összegzés,

- egyedi és közös publikációk az összegyújtött ismeretanyag kiegészítésével.

A multinacionális cégek leányvállalatai a kutatókat elsősorban korábbi tudományos együttmúködésük alapján fogadják. 2010 májusáig tizenkét hazai, két német és két izraeli vállalkozásnál történt felmérés. Miután kutatásunkkal vállalati adatokat nem kívánunk publikálni, ezért csak azt tudatjuk, hogy a cégek a gazdaság mely területén múködnek:

- bank- és biztosítási szektorban: 3,

- energiaipari szolgáltatás területén: 4,

- szoftverfejlesztés, hardvergyártás és -eladás: 3 ,

- ipari szektor: 3 ,

- kereskedelmi, eladási láncok területén: 3.

Felmérésünk így nem egy kiválasztott szektorra irányul, hanem a gazdaság széles területét fogja át. Az in- terjúk egy egységes „Szakmai beszélgetések kérdései” címú kérdőív alapján történtek, és a cégek jelenlegi ERP struktúrájának felmérésére, fejlesztési, egységesítési és az ERP globalizációs lépéseire irányulnak. A beszélgetések 3-6 oldalas összefoglalói minden tanszék részére hozzáférhetốk. A kutatás eredményeképpen Gronau három kiindulási modelljétôl (Gronau, 2008) különbözô, további három globalizációs modellt alakítottunk ki, melyek az elmúlt néhány év fejlesztési irányait fedik le. A kutatási adatok értékelése alapján a 3. fejezetben definiált globalizációs modellekhez a vizsgált cégeket az alább megadott számú esetben tudtuk hozzárendelni:

Modell-3: nyolc eset, Modell-4: egy vállalkozás, Modell-5: három nemzetközi cég, Modell-6: négy multinacionális cég.

Felmérésünkból azt a következtetést is levontuk, hogy a különbözố rendszerstruktúrák, azok üzemeltetési szervezése, nem iparági, hanem kifejezetten cégen belüli IT-stratégiafüggőek. A vállalkozások többségénél az ERP-k régiószintú összevonása és üzemeltetése - mint fejlesztési irány - mutatható ki (kilenc eset), egy európai székhelyú vállalkozás esetében a központi rendszerhez való integrálás és az ott megszervezett üzemeltetés (Modell-5) volt a cél. Egy világméretú, biztosítási konszern az egyes országspecifikus rendszereit csak részlegesen globalizálja, tehát az önállóság megtartását helyezte előtérbe (Modell-4). Négy esetben túzték ki egyes, kiemelt feldolgozási folyamatok kiemelését az országszintú ERP-kból és azok centralizált kezelésének megoldását (Modell-6). A 2009-2010-ben folytatott kutatásunk alapján kijelenthető, hogy a jelenlegi helyzetet még döntóen az országspecifikus és a centrális ERP-k közötti off-line (pl. Excel táblás) kapcsolatok jellemzik, de az IT fejlesztési koncepciók a Modell-5 és Modell-6 irányába mutatnak.

\section{Globalizált ERP-modellek}

A csak egy országon belül múködő vállalkozásokkal szemben a nemzetközi cégek több (a Shell esetében például százat is meghaladó) országszintû́ ERP-n keresztül oldják meg adatfeldolgozási és irányítási feladataikat. A Shellnél 2005-ben döntés született, hogy ezt a „kavalkádot” áttekinthetô struktúrába rendezzék, vagyis a konszernen belül a meglévő és különböző ERP-rendszereket egységesítsék (Kulcsár, 2006).

Eggert és Forholz szerzók 34, a német piacon ajánlott ERP-rendszert elemeznek, melyek egy nemzetközi vállalkozáson belül az egységes adatfeldolgozási struktúra kialakítására szolgálhatnak. Vizsgálati szempontjaik minden rendszer esetében a következók: iparági/szakterületi irányultság, országspecifikus eltérések figyelem- 
bevétele, nyelvi kezelhetôség (pl. arab, perzsa stb.) és a Gronau-féle globalizált modellekhez (lásd 1. ábra) rendelhetôség (Eggert - Forholz, 2009).

A globalizált ERP-k a nemzetközi cégen belül egységes rendszert alkothatnak, pl. azonos adatbázis-kezeléssel, standardizált integrációs felületekkel. Kutatásaink szerint a kialakuló feldolgozási struktúra felépítését tekintve nem homogén, hanem országspecifikus és többszintû.

- Az országspecifikus kialakítást a Stäubli AG példája szemlélteti. Itt egy gépgyártó és a termékeit leányvállalatokon keresztül értékesítô, berni (Svájc) székhelyú konszern a gyártóhelyeken (különbözó országokban) a pénzügyi és termelésirányítási modulokat, míg az ázsiai értékesítő cégeinél a CRM-rendszert, a központban pedig a pénzügyi ellenôrző és a vezetôi rendszerrel kapcsolatos feldolgozásokat vezette be (Szabó, 2009c).

- A többszintú ERP-struktúra kialakításának példáit a régiókba szervezett feldolgozások jelentik. Egy amerikai székhelyú, de az egész világot átfogó szoftverértékesítő cég több kelet-európai ország irányítására szolgáló székhelye Budapest. Az országok szintjén egy most bevezetett CRM a feldolgozási rendszer központi eleme. Budapesten vonják össze a forgalmi adatokat, majd továbbítják a következô régiós vezetési szintre, ahol már az európai szintú összesítés történik (ELTE, 2009).

Általánosságban jellemzố a nemzetközi cégek ERPstruktúrájára, hogy az országszintú feldolgozások (modulok) a centralizált (központi) rendszerbe adatokat továbbítanak, így biztosítva a konszernszintú irányítás információs igényeit.

A vázolt ERP-struktúrák modellekbe sorolhatók. Gronau egy piaci szegmenst vizsgálva (autóipari beszállítói cégek rendszerei) három modellt állított fel, melyek a vizsgált konszernek centralizált feldolgozásának szempontjából szemléltetik az országszintú ERPrendszerek csoportosítását (Gronau, 2008).

Az általunk folytatott kutatások a gazdaság több szférájában (gyártás, szolgáltatás, kereskedelem, informatika, banki és biztosítási szektor stb.) jelen lévô nemzetközi cégek egy-egy vállalkozására terjedtek ki. A szakértói megbeszélések alapján, a vállalkozások rendszereinek besorolására a Gronau-féle három alapmodell kevésnek bizonyult, így további három új
1. ábra

Globalizált ERP-modellek

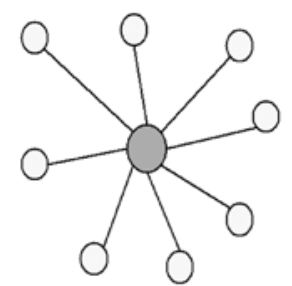

Modell-2:

Kōzponti ERP kommunikál minden leányvállalat egységes rendszerével
Modell-3:

Központi ERP kommunikál

minden leányvállalat

különbōzỏ rendszerével

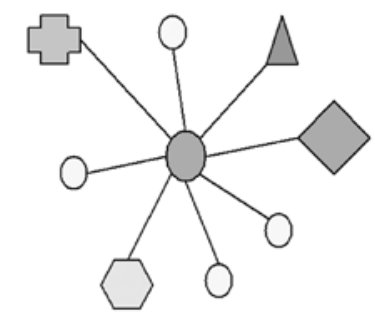

(Forrás: saját szerkesztés a Gronau, 2008, Bild 3. ábrája alapján.)

modell kialakításához jutottunk el, hogy a konszern központi feldolgozásához kapcsolódó globalizációs tendenciát leírhassuk.

A 4. modell (lásd 2. ábra) olyan vállalkozások rendszerstruktúráját írja le, melyeknél a központi irányítás a cégvásárlások elôtt is meglévő, országspecifikus rendszerek megtartását, azok országon belüli, decentralizált továbbfejlesztését túzi ki célul. Tipikus példája ennek a modellstruktúrának egy hollandiai székhelyú, nemzetközi biztosító, melynek irányítási koncepciója figyelembe veszi, hogy az egyes országok eltérő törvényi szabályzása miatt egy-egy biztosítási üzletágat (pl. életbiztosítási vagy vagyonbiztosítási konstrukció) csak országspecifikusan lehet kialakítani. A modell jellegzetessége, hogy a különböző országok eltérő ERP-rendszerei néhány modult közösen használnak, azok egy konszernen belüli intranethálózaton keresztül minden telephelyról elérhetốk. Azonban itt is hosszú távú célként szerepel, hogy a központi feldolgozásba egy standardizált rendszeren keresztül kerüljenek be a vezetési információk.

2. ábra

Intraneten kommunikáló ERP-rendszerek

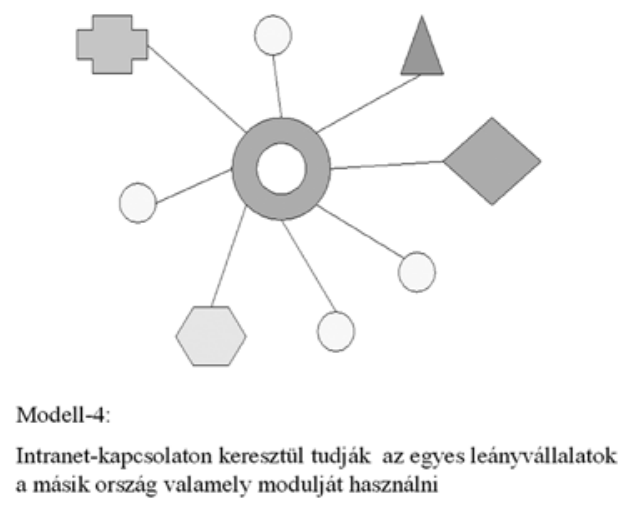

ányvállalatok a másik ország valamely modulját használni 


\section{Országszintú rendszerek centralizált kezelése}

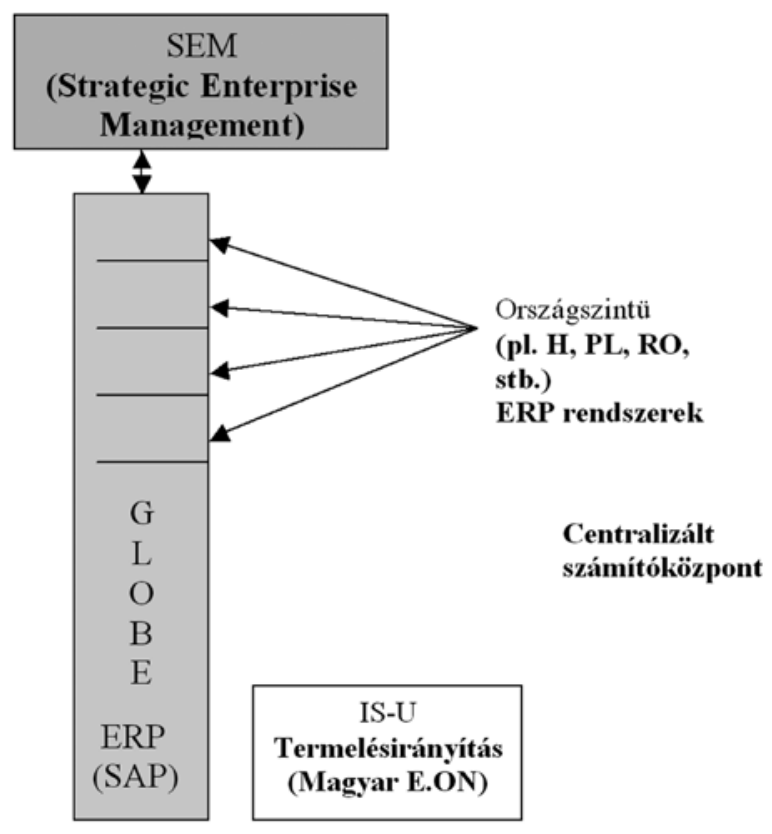

3. ábra A kutatás eredményeként egy további ERP-modell (6. modell) kialakítása is szükségessé vált, mely az ERP-struktúrákból kiemelt egyes üzleti folyamatok centralizált kezelését szemlélteti. Több cég esetében találkoztunk azzal a koncepcióval, mely a régión belüli egyes adminisztratív tevékenységeket összevontan kezeli. Így például a számlák feldolgozását, a kifizetések indítását a régió országainak ERP-rendszereiből kiemelték és centralizáltan végzik. Ez nemcsak költségcsökkentést eredményez, hanem lehetőséget ad arra is, hogy a régióra kiterjedô pénzügyi feldolgozással a kontrollinginformációkat naprakészen kezeljék. Több kutatott cégnél találkoztunk a call centerek régiószintü összevonásával is. Ez a költségcsökkentés mellett az internacionális cég egységes piaci arculatának kialakítását, a szervizelési erőforrások centralizált, hatékony kezelését is eredményezi (ELTE, 2010).

Az ERP-modellt, mely egyes üzleti folyamatok centralizált kezelését (pl. országon vagy régión belül) tartalmazza, a 4. ábrán mutatjuk be.

4. ábra.

\section{Üzleti folyamatok centralizált kezelése}

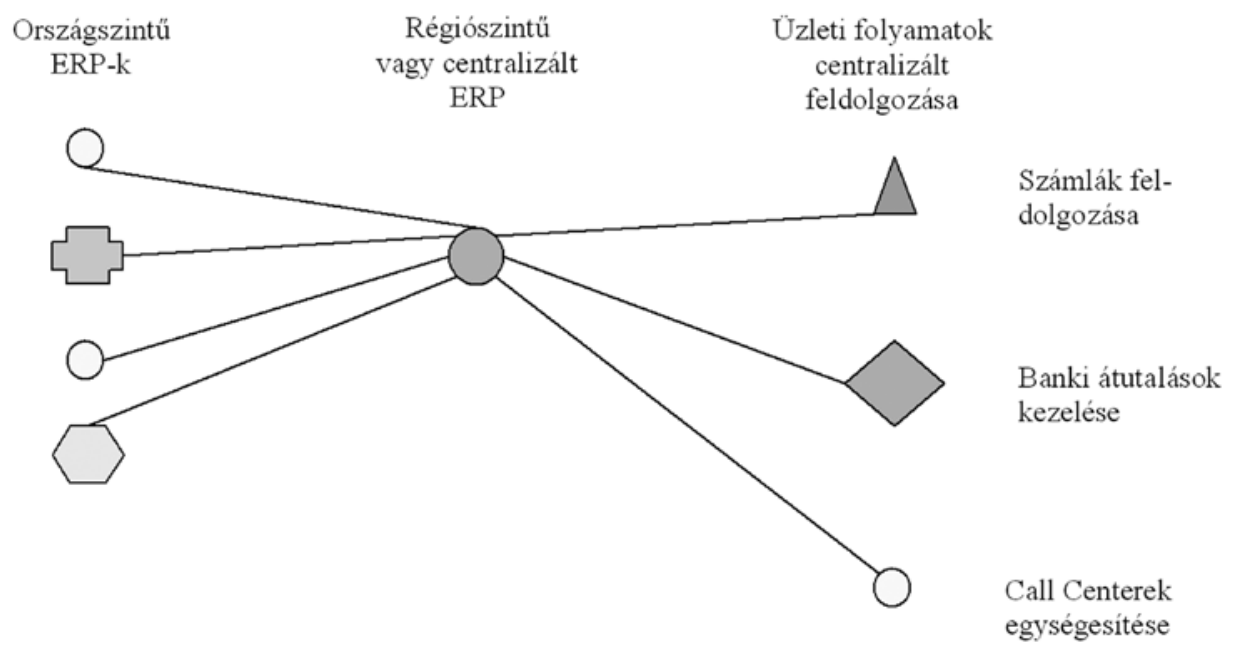
rendszerek egyik irányába mutat. Lényegi jegye, hogy magában hordozza a konszernhez tartozó különbözô országokban üzemelő ERP-rendszerek egységesítését, vagyis a konszernen belül egy kiválasztott ERP-re (pl. SAP) való kötelező áttérést. Ezen túlmenóen centralizálja a hardverkapacitást is, és egy központosított helyen futtatja az összes (régióbeli) ERP-t. Tipikus példa erre egy európai energiaszolgáltató cég 2013-tól életbe lépó IT-koncepciója, mely a németországi számítóközpontjába fogja egységesíteni az európai országspecifikus feldolgozásokat. A központi irányítás is egy standardizált modulon (SEM = strategic enterprise management) keresztül éri el az egyes leányvállalatok rendszereit, és nyer konszolidált adatokat a vezetési modulok számára. A távlati koncepciót a 3. ábrán szemléltetjük.

Hasonló elképzelés távlati kialakításával találkoztunk még egy müncheni székhelyú, nagyfeszültségú berendezések gyártásával és informatikai üzletággal rendelkező világcégnél is.

\section{Piacorientált ERP-modulok (CRM, SCM) globalizációs trendje}

A kutatott gyakorlati esetek egy részénél nyilvánvalóvá vált, hogy a nemzetközi cégek a beszállítói és a vevői oldali folyamatok ERP-moduljait - a többi feldolgozási funkciótól elkülönítve - több országra egységesítve, globalizáltan kezelik. Ezt a tendenciát támasztja alá a témára vonatkozó szakirodalom feldolgozása is. A publikációk egy jelentôs csoportja az ügyfélkapcsolat-kezelési $(\mathrm{CRM}=$ customer relationship 
management), az ellátásilánc-menedzsment ( $\mathrm{SCM}=$ supply chain management) rendszerek, illetve a piaci kommunikációt felügyelő megoldások globalizálódását tárgyalja. Kiemelt kezelésük azért is érthetô, mert sok multinacionális vállalkozás egyik fố tevékenységi köre a globális és helyi piacokon való fellépés, így a vevôiszállítói kapcsolatok egységes, hatékony felügyelete. Az országokon átnyúló ellátási láncokat valós időben kell ellenőrizni a vállalatoknak, hiszen ezek új kockázatokat jelenthetnek több területen is. Ilyen kockázatok lehetnek például a késôi szállítás vagy a feketepiaci értékesítés (Hill, 2009).

Egy sikeres projektról számol be a Kidrobot ${ }^{1}$ cég, amely az egész világról importálja termékeit az Egyesült Államokba, ahol országszerte számos bolttal rendelkezik. Az értékesítési hálózatuk irányítását egy global supply chain (globális ellátási lánc) megoldás képezi. A rendszerrel tovább növelték folyamataik hatékonyságát, így például a bankkártyák kezelését a B2B üzleteikben, vagy az értékesítés lebonyolításának sebességét (Kidrobot, 2009).

Ankhen global supply chain 2.0 megoldása már egy hatékonyan továbbfejlesztett rendszer. A jelenlegi ERP-rendszerek ugyanis nem képesek a nap 24 órájában az ellátási folyamat egyes lépéseinek (fizikai technológiák) és az ellátási lánc pénzügyi eseményeinek valós idejú összekapcsolására. A fizikai technológiák bevezetése esetén az RFID és a GPS adta lehetôségekkel a pénzügyi adatokat proaktívan lehet integrálni a folyamat lépéseihez. Az így összekapcsolt feldolgozási funkciókkal egy on-demand (távoli szolgáltatásként igénybe vehetô) szolgáltatást alakítanak ki, és egy valós idejú piaci felügyeletet, áttekintést valósítanak meg a cég teljes vertikumára (Ankhen, 2010).

Az ERP-rendszerek globalizálódása azt is eredményezi, hogy a vállalkozások újragondolják és optimalizálják folyamataikat. Ezek során sok cégnél az ellátásilánc-menedzsment az egyik legfontosabb terület. Az Aberdeen Group statisztikáját érdemes itt bemutatnunk, mely szerint a vállalatok $16 \%$-a tervezi újra a global supply chain (globális ellátási lánc) folyamatait, vagy beszerzési hálózatát, a vállalatok 41\%-a mindkettốt, tehát az ellátási láncot és a hálózatot is átalakítják, és csupán $18 \%$-a az, ami csak az ellátási lánchoz nyúl. További érdekes statisztikai adat, hogy a vállalatok 64\%-ának az ellátásilánc-menedzsment centralizálása az egyik fó célja. Ugyanebben a tanulmányban, egy kínai vállalat esetén, a globalizálódás másik kérdését elemzik, a „best practice”, vagyis az iparági „legjobb” megoldások esetét. A ChemChina cég esetén ez volt a döntố kérdés, ami alapján az SAP-SCM oldalára dőlt a mérleg (Wheatley, 2008a).
Piacorientált globális ERP-rendszer létrehozását határozta el a Fossil. A vállalatcsoporthoz 300 értékesítố kereskedő vállalkozás tartozik globális szinten, összefogásuk és hatékony menedzselésük csak egy központosított rendszerrel válhat lehetôvé. Célul tưzték ki, hogy az új ERP gyorsítsa a vevơi megrendelések feldolgozását, melyet még a munkafolyamatok fejlesztésével és az eróforrások hatékony feldolgozásával is össze akartak kapcsolni. Választásuk az SAP megoldásaira esett, amelyhez a PkMS (warehouse management system = raktárkezelőrendszer) rendszert is integrálták. A kialakítást tekintve két központ gyújiötte a 300 kereskedő adatait, Dallasban (USA) és Eggstattban (Németország). A rendszer továbbfejlesztésénél az SAP AFS (Apparel and Footwear Industry Solution) megoldása mellett az UC4 Workload Systemet is alkalmazták, és ezzel elérték azt a kitúzött célt is, hogy a rendszer képes volt párhuzamosan indítani a megrendeléshez kapcsolódó munkafolyamatokat az SAP-n belül (Hess, 2009).

\section{A globalizált ERP-rendszerek elônyei}

Megfigyelhetô, hogy az internacionális cégek a korábbi, különböző országspecifikus rendszereiket egyrészt globalizált ERP-megoldásokba integrálják, másrészt egyes feldolgozási területeket, folyamatokat a helyi feldolgozásokból kiemelve centralizáltan valósítanak meg.

Milyen elónyöket biztosítanak az ERP globalizációs megoldások keretében a feldolgozási folyamatok centralizálására irányuló törekvések? A kérdésre a feleletet több szakirodalmi és gyakorlati példa bemutatása után adjuk meg.

Njaa tanulmányában leírja, hogy a sok negatív kritika ellenére, számos előnnyel jár az áttérés egy globalizált ERP-rendszerre. Példaként hoz fel egy energetikai vállalatot, ahol az alrendszereiket egyetlen globális ERP alá vonták össze. Két projektet hívtak életre, az egyiket a pénzügyi, a másikat a múködési feladatokra. 200 alkalmazott 16 hónapjába telt a „go live” (éles indulási) állapot elérése. Az elért előnyök a költséghatékonyság növelése, az információmenedzsment magasabb foka, válságmenedzsment támogatása, a globális ügyfelek hatékony kiszolgálása, és a legfontosabbat sem szabad elfelejteni, az ellátásilánc-menedzsment megváltozása az optimálisabb múködés érdekében (Njaa, 2008).

A következő, sikeres európai példánk a Rexam, a csomagolóóriás, mely 21 gyárat tudhat EU-szerte a multinacionális vállalatban. Számos országspecifikus alrendszert kellett integrálni egy feldolgozási módszerbe. Korábban, a különbözó gyártási folyamatokat tekintve, leginkább a termelési információ feldolgo- 
zásának szintjén léptek fel problémák, mint például a gyártási statisztikák előállítása, minőségi paraméterek felügyelete, erőforrás-kihasználtság mérése. Az adatokat végül is egyetlen globális SAP ERP-rendszerbe öszszesítették. A feladatot nehezítette, hogy kilenc nyelvet kellett összehozni, hiszen virtuálisan ugyanazon a képernyőn dolgoznak a munkatársak. A végső eredmény egy letisztult SAP-rendszer és a hozzá kapcsolódó Minitab Six Sigma System lett, ami a gyártás minőségére ügyel, és ha ott problémát lát, értesíti a megfelelő vezetối szintet (Gooch, 2008).

A globalizálódás egyik technológiája az SaaS (Software as a Service $=$ szoftver mint szolgáltatás) rendszerek létrejötte. Ezt a technológiát egyre több ERPrendszerben is alkalmazzák már. Itminster egy optikai termékeket gyártó angol vállalat webes menedzselhetőséggel ellátott ERP-rendszert vezetett be. A funkciók bárhonnan elérhetốk, például utazás közben, munkában vagy otthonról. Az SaaS-technológiával rendelkező ERP alkalmas a földrajzilag távol lévő alkalmazottak együttes munkájának kialakítására is, tehát az internetes technológia elônyeit és ennek jövốbeli használatát alapozza meg (Gooch, 2008).

A magyarországi illetőséggel is rendelkező Laird Technologies informatikai vezetôje, Todd Rumsey (CIO) elmondta, a vállalat továbblépett a globalizálódásban. Olyan rendszerfejlesztést indított el, amellyel a több országban található gyáraik egyetlen rendszert érnek el (lásd 1. ábra, Modell-1), de úgy, hogy a gyárak ne veszítsék el függetlenségüket, tehát országspecifikus jegyekkel és paraméterezéssel is rendelkezzenek. A koncepció megvalósításával elérték a céljukat, olyan globális rendszert alakítottak ki, mellyel a kapacitásokat és a megrendeléseket sokkal gyorsabban tudják kezelni, kiszolgálni, mint korábban (Wheatley, 2007a).

Kutatásaink alapján két további magyarországi példát lehetne felhozni arra, hogy egy központosított rendszer interfészeken keresztül érhető el egy országspecifikus feldolgozásból. Egy pécsi, dohányipari termékeket gyártó vállalatnál a németországi központ a pécsi telephely adatfeldolgozási függetlenségét meghagyva, SAPrendszerre állított át több vállalati folyamatot. A vállalaton belül számos további, az SAP-tól eltérô alrendszer is található. A HR-folyamatokat a Nexxon rendszer, a gyártási folyamatokat a vállalat saját készítésú rendszere kezeli. A teljes vállalati ERP-t interfészek sora kapcsolja össze és egyesíti a német központ felé. (A vállalatra az 1. ábra 3-as modelljét lehet alkalmazni, ahol az anyavállalat központi ERP-rendszere kommunikál a leányvállalat különbözô rendszerével.)

Ugyanez a koncepció figyelhetô meg egy dél-dunántúli energetikai vállalatnál, melyet egy nemzetkö- zi konzorcium irányít. A vállalat a saját rendszeréból interfészeken keresztül kommunikál az anyavállalat ERP-jével. A központi vezetés egyetlen globális rendszerben látja a jövőt, de a fejlődés jelenlegi szakaszában még csak egyes rendszerek összekapcsolása történt meg, az ERP-átállítás a jövố zenéje. Amennyiben a leányvállalat profitot termel, ebben az esetben nem foglalkoznak a helyi rendszerekkel. Ha a nyereségesség csökken, akkor a központi key performance indicators, KPI (kulcsfontosságú teljesítménymutatók) alapján is kezelni tudják a problémákat. Az anyavállalat egy globális rendszerben is képes figyelni az összes leányvállalatánál futó pénzügyi folyamatokat, vagyis bizonyos feldolgozások adatai az egyes régiók összesítése nélkül is hozzáférhetốk (ELTE, 2010).

A példák alapján is kimondható, hogy a cégfelvásárlások egyik velejárója a meglévő vállalati feldolgozásokból a központi kapcsolódások gyors és költségkímélő kialakítása, vagyis az interfészek létrehozása, legyen az bármilyen rendszer, akár szakértôii, akár ERP. Ennek fô oka, hogy az új tulajdonosok minél elóbb profitot akarnak látni, és nem pedig újabb befektetést, amivel az egész rendszert egységesíthetnék. Egy új ERP-re való átállás, annak bevezetése, idôt és pénzt igényel, de ez egy felvásárlás után általában nem szerepel az elsődleges célok között.

Egy egységes ERP-re való átállás költséges folyamat, melyet nagyszámú szakirodalmi értekezés tárgyal. Elemzésünk szerint egy ERP-bevezetés nem egyenlő egy szoftver felinstallálásával, hiszen maga a kiválasztás, tervezés és elôkészítés is hónapokat (éveket) vesz igénybe. Mi határozhat meg egy átállítási döntést? Wheatley publikálta, hogy a globalizálódás az üzleti szoftverek világában a statisztikák szerint, 59\%-ban az alacsonyabb gyártási költségek $51 \%$-ban a gyorsabb szállítás, 41\%-ban az ügyfélkapcsolatok irányába történik, vagyis itt várnak hatékonyságnövelést (Wheatley, 2007a).

Érdemes egy üveg Coca-Cola-ra gondolni! A cégnek világszerte több mint 1000 gyára van, 45 országban, 18 nyelven történik a kommunikáció. Az egységes ERP-re való áttérés olyan jelentôs erőforrást igényel, ami nem megy egyik napról a másikra. De ez a jövő, és ezt az irányt célozta meg az általunk felmért cégek jelentős része is! Coca-Cola az SAP együttmúködésében HR-területen 100\%-ban, pénzügyi oldalon 95\%ban és ellátási lánc esetén 98\%-ban fedte le a globális megoldásokat. Ha a kibővített adatokat nézzük, és nem csak a kizárólagosan Coca-Cola egységeket, hanem a beszállítókat, partnereket is hozzászámoljuk, akkor 80 országban 70 ezer ember munkáját segíti a globalizált ERP nap mint nap (Wheatley, 2007a). 
A Volvo globális ellátásiláncmenedzsment-rendszerét is az új irányelvek szerint alakították ki. Nem lokálisan és regionálisan, hanem globálisan hozták létre és optimalizálták. Olyan elónyökkel szolgált a bevezetés, mint a beszállítók, forgalmazók és a fogyasztók közötti jobb információkommunikáció, javuló szállítmányozás, logisztika. Megvizsgálták, hogy a folyamatos termékfejlesztés során mely már meglévő elemek kapcsolhatók be az ellátási láncba, az új elemeket már eleve a lánchoz tervezték. Egy új elemnek (egységnek) a termeléstervezéshez való kapcsolódásán keresztül szimulációs futásokkal a kapacitás/terhelés változás elôrejelzését, illetve a gyártási prioritások kezelését is megoldották (Wheatley, 2008).

Egy további sikeres ERP-bevezetésre a következő példa szolgál.

„Nem egyszerú feladat az összes rendszert eredményesen implementálni" - mondta Cozzone, a Colorcon Inc. informatikai vezetóje. A cég globális ERP-megoldásának létrehozása után, 50\%-kal elóbb zárta le a fókönyvet, ami jelentős előrelépés volt a vállalat életében. Az egész nem más, „mint változásmenedzsment”, ennyire egyszerúsítette le az átállítási lépéseket a vállalat vezetôje. Ez részben igaz csak, hiszen az üzleti folyamatokat standardizálni kell, a különböző kultúrákban azonos eredményeket kell elérni, az adatintegritást magas szintre kell helyezni, az országok törvényeit, rendelkezéseit tiszteletben kell tartani. Hosszan lehetne sorolni a feladatokat, de egy jól kiválasztott, múködő globális ERP mindezeket automatikusan tudja és kezeli is (Hoffman, 2007).

A globalizált ERP-rendszerek kialakítása internacionális vállalkozásoknál napjaink törekvése. Ebbốl az üzletből minden ERP-rendszert fejlesztô cég ki akarja venni a részét, növelni akarja piaci részesedését. Ehhez új technológiákat, szoftvermegoldásokat, szolgáltatási koncepciókat (pl. SOA) fejlesztenek ki.

A Microsoft NET Framework létrehozásánál is az egyik szempont az ERP-rendszerek támogatása volt. Számos vállalat alkalmazta a SOA (service-oriented architecture $=$ szolgáltatásorientált architektúra) megoldásoknál a Microsoft rendszerét (Hiraoka, 2007). Természetesen az országspecifikus rendszerek öszszekapcsolásának interfészkérdését nemcsak a Microsoft célozta meg. A HCL Technologies is létrehozott egy framework-öt (keretrendszert) a különbözó ERPrendszerek közötti rések betömésére, mellyel elósegítette a rendszerek integrálását (Fulcher, 2007).

A szakirodalomban a gyártóktól független szerzók is a SOA-támogatásban látják a jövőt, ami standard megoldásokkal összekapcsolja rendszereket. Ugyanakkor kihasználják az internetgazdaság adta egyéb le- hetôségeket, mint például az XML-nyelvet és az alapvető kommunikációs rétegeket a hálózaton (Qureshi, 2007).

Az AMR Research által szolgáltatott statisztikák is a SOA-technológiára épülve készítettek elemzést, melyek szerint a vizsgált vállalatok 26\%-ban ERPrendszerekbe, $21 \%$-ban gyártási rendszerekbe, illetve ellátásilánc-rendszerekbe 16\%-ban fektettek be. Növekszik a key performance indicators (KPI) területével kapcsolatos feldolgozások aránya, amikkel azonos teljesítményeket lehet összehasonlítani, és nem kell tudnia az adott ERP-felhasználónak, hogy mi található a számok mögött (Jutras, 2007a).

Egy új ERP-rendszerre történő átállásnak több indoka van. Vannak olyan szerzók, akik szerint sok vállalkozáson belül az ellátási lánc (SCM) és a hozzá kapcsolódó folyamatok súlya a fejlódés részét képezik. Ez amolyan automatikus ,természeti” törvény az iparban, tehát nem játszik aktív szerepet, hanem inkább automatikusan következik be. Stratégiai fontosságú ilyen cégek szempontjából az SCM hangsúlyozott kezelése, melyet a technológiai-gazdasági fejlődés követel ki magának. A szállítási lánchoz kapcsolódó területi rendszerek fejlesztése, mint például pénzügy, tudásmenedzsment, a cég piaci pozícióinak növelését alapozza meg, melyet egy korszerú ERP-re való átállás tesz lehetôvé (Gunasekaran, 2007).

Más szerzók az új ERP bevezetését célratörően indokolják. Egy régen kifejlesztett rendszer helyett költségkímélóbb egy modern megoldás bevezetése, amit a Fabory példája is bizonyít. „A Borstlap b.v. az SAP R/3 bevezetése elótt egy AS/400-as rendszert, a TOTICSot használta közel 20 éven keresztül. Bár a program kifejlesztésekor valószínúleg tökéletesen kielégítette a vállalkozás akkori igényeit, sốt a folyamatos fejlesztésekkel azt valamennyire szinten is tartották, mégis elavult." (Tóth, 2008) Ez a kényszerítő ok, tehát az elavulás miatti rendszerváltás szükségszerúsége, sok publikációban szerepel.

Eddigi példáink az ERP-re való áttérés indokait, előnyeit mutatták be a nagyvállalati megvalósításoknál.

Ugyanakkor nem csak a nagyvállalatok kiváltságai a globalizálódó ERP-rendszerek által nyújtott piaci lehetőségek! A kis- és középvállalkozásoknak (kkv) szánt rendszerekben is megváltozni látszanak a nézetek. Azokat a technológiákat, amiket a multiknál már alkalmaznak, a kkv-k számára létrehozott megoldások is tartalmazzák. Így a kis- és középvállalkozások információtechnológiailag előreléphetnek, megkönnyítve ezzel a felvásárlást, illetve a nagyobb kategóriába való lépésnél a vállalati információmenedzsmentet. 
Az ERP-szállítók felismerték a kkv-k fontosságát, és számukra is olyan megoldásokat kínálnak, amivel nem maradnak le a piaci versenyben (Gold, 2007). Tehát a kkv-piacon is számolni lehet egy korszerú ERP-re való átállási trenddel.

Cindy Jutras, az Aberdeen Group munkatársa szerint minden ötödik nemzetközi vállalat központosította ERP-rendszerét, és egypéldányos tárolással (single instance) oldotta meg a központosítást. A több ERPrendszert használó vállalatok aránya 50\%, tehát jelentốs lemaradás található esetükben a globalizálódásban. Jóllehet a forrásban emlegetett statisztikai felmérés szerint, a vállalatok $83 \%$-a tervezi a globális növekedést, ami az ellátási lánc magasabb fokú komplexitását eredményezi. A központosított ERP is jelentôsen hozzájárult, hogy ezek a vállalatok az automatizált munkafolyamataikkal (workflow) hatékonyságnövelést értek el, például a gyártásnál $22 \%$, a szállításnál $18 \%$ és a jövedelmezőségben (profitability) is $28 \%$-kal az átlag feletti teljesítményt nyújtanak (Jutras, 2007b).

Egy vállalatirányítási információs rendszer bevezetésénél át kell hidalni a vállalat stratégiai céljai és az ERP-implementáció közti szakadékot, különben az elképzelés nem lesz sikeres. A vállalati céloknak kell alárendelni az ERP-rendszert, nem pedig fordítva. A folyamatokat ugyan standardizálni kell, de ez nem jelenti azt, hogy egy kiválasztott rendszerbe kell illeszteni óket (Malhotra, 2009).

Ugyanezt mondta a Hauni Magyarország informatikai vezetóje. A gyártásban olyan folyamatok vannak, amiket a standard SAP nem tud kezelni, nincs kettó ugyanolyan alkatrész, ez utóbbi az egyedi megrendelôi igények miatt nincs, tehát a gyártás vevôspecifikus. Az anyavállalathoz kapcsolódó teljes SAP-illeszkedés tehát nem valósítható meg, ezért megtartották a saját fejlesztésú rendszereiket, amivel tökéletesen ki tudják elégíteni a gyártási és kapcsolódó folyamataik feldolgozási elvárásait (ELTE, 2010).

Az elsố lépés egy ilyen globális ERP bevezetésénél az üzleti folyamatok standardizálása. A Sandvik Mining and Construction cég 40 országban standardizálta üzleti folyamatait, ezért a fázisért az országokon felüli ITcsapat felelt. Az egész folyamatra 3-4 évet szántak, és a Svédországban lévő fóhadiszállásról irányították az átállás tervezését, annak lezárása után indulhatott az egységes ERP bevezetése (Clark, 2006).

A fejezet elején feltett kérdésre összefoglalóan kijelenthetô, hogy egy nemzetközi cégnél az ERPglobalizálás egységes piaci arculatot, fellépést, és ezáltal hatékonyságnövelést, a centralizált ügyviteli folyamatokban költségcsökkentést, a cégvezetés számára a központi MIS (Management Information System = vezetői információs rendszer) rendszeren keresztül nagyobb áttekintést, és ezáltal gyorsabb döntéshozatalt eredményez.

Az előnyök bemutatása után a következő két fejezetben a rendszerek továbbfejlesztési irányait tárgyaljuk.

\section{A globalizált ERP-rendszerek fejlődési tendenciái}

Az utóbbi években olyan megoldásokkal álltak elő az ERP-gyártók, mint a SaaS vagy az Amazon komplett ERP megoldása, ahol a saját cloud (számítási felhô) rendszereiken futó megoldásokat kínálnak (Amazon, 2009). Voltak olyan kutatók, akik a felhasználói felület kérdését elemezték, többek között a feltörekvő generációk DNS-be kódolt informatikai tudását elemezték (Wailgum, 2009a). Olyan megoldások is születtek, melyet a Rimini Street képvisel. A cég számos elégedetlen SAP-ügyfélnek kínál megoldásokat, feleakkora költséggel, mint az SAP (Wailgum, 2009b).

Ezek a fejlesztések azonban csak a futó rendszerek foltozását jelentik. Az újabban ajánlott ERP II generáció már nyitott kifelé, szinte az összes vállalati funkció és folyamat lefedett bennük. Olyan megoldás is született, ahol a felhasználók egy keretrendszert kaphatnak, amibe saját maguk állíthatják be a folyamatokat, ha nem akarnak költséges bevezetési procedúrát, és nem akarnak tanácsadókat fizetni (Wailgum, 2009a). Ezt úgy lehetne megfogalmazni, hogy a szoftvert, illetve a szolgáltatást személyre lehet szabni, eldöntve, hogy mely folyamatok, mely képernyóelemek, mely adatok szükségesek a munkájukhoz. Ezt a megoldást az SAP már kidolgozta kkv-szintre, az SAP Business ByDesign rendszerével, ahol az infrastruktúrát, a szervizt és a supportot (támogatást) is megkapja a felhasználó. A vevố mindezeket egy szabványos böngészôvel tudja kezelni és személyre szabni (SAP, 2009a).

Egy friss felmérés szerint a vállalatok $39 \%$-a részesíti előnyben az egy ERP-gyártótól származó terméket. Döntésükben közrejátszik, hogy számukra a legfontosabb elemek frissítése, például a mobilos együttmúködések, komplett CRM-megoldások és az üzleti intelligencia egy kézben van (ITweb, 2009). Az Oracle elemzése szerint van még elég terület, melyeket fejleszteni kell. Olyan problémákat sorolnak fel a vállalatok, mint például a túl drága karbantartás, a túlontúl komplex megoldások, és ezért nem elég rugalmasak a rendszerek, illetve nehéz a használatuk. Sok cég nem tudja, valójában mennyiben térült meg az ERP bevezetése (Farid, 2009). A továbbfejlesztések tehát teljes erővel folynak.

Véleményünk szerint az ERP jövőjét az alábbi fóbb folyamatok fogják meghatározni: 
- BPO (Business Process Outsourcing). Az üzletifolyamat-kiszervezés keretében egy vagy több üzleti folyamatot adnak át egy külsố szolgáltatónak (pl. számlázások), melynek feladata lesz az átadott tevékenységek teljes mértékú irányítása, bonyolítása egy előzetesen meghatározott, mérhető teljesítménymutató alapján. Ezzel alacsonyabb költségeket, jobb kockázatmenedzsmentet és javuló minőséget lehet elérni (SAP, 2009b).

- Újabb tevékenységek integrálása. Mindig is az ERP részét képezték az integrált folyamatok, a bővítési trend nem állt meg. Újabban olyan folyamatokat integrálnak, melyek még nem találhatók a rendszerben, olyan elemeket visznek be, amelyek az adott tevékenység/iparág hatékonyságát fokozzák. Korábban ilyen hiányzó folyamatokat fedtek le a CRM és az SCM beépítésével, napjainkban bóvülhet a kör az e-SCM-, e-CRM-rendszerekkel, illetve egyéb megoldások (pl. utazásmenedzsment, rizikóanalízis) integrálásával.

- Racionalizáció. Az elóbb tárgyalt ERP-globalizáció és -integráció során olyan bonyolult megoldások alakulhatnak ki, melyeket a használati tapasztalatok alapján racionalizálni szükséges. Meg kell vizsgálni tehát, hogyan lehet leegyszerúsíteni a folyamatokat, a köztük zajló kommunikációt, és az iparági megoldások során lehetôvé kell tenni a felületek, folyamatok testre szabását. Cél tehát egy hatékonyabb információmenedzsment megvalósítása.

- Közösségi ERP kialakítása. Hasonlóan az eBusiness megoldásokhoz, az ERP-piac is arra törekszik, hogy a közösségek irányába lépjen tovább. Egy ERP használatánál a közösség már adott, a csoport, az osztály, a vállalat. Ezen egységek kommunikációját, menedzselését és tudását kell megfelelően kezelni. Feladat tehát a közösségi hálózatok által generált igény beépítése és kezelése, vagyis a vállalaton belül jöjjenek létre blogok, fórumok, wikipedia, dokumentummegosztás, vagy akár egy kapcsolati háló (Hughes, 2009). Természetesen léteznek már megoldások ezen a területen, például az SAP Knowledge Management, ami az SAP-rendszer alapjaiban található, az információintegráció komponensei között található meg a Netweaverben (SAP, 2009c).

- Mobilitás. Kétségtelenül a mobil alkalmazásoké a jövő, ez nemcsak az ERP-piacra vonatkozik, globális szinten is igaz. Ma már számtalan eszközzel el lehet érni a rendszereket (mobiltelefonok, laptopok, netbookok, okostelefonok), és ez csak a kezdete a teljes mobilitásnak. A fejlesztők és a kutatók egyaránt úgy gondolják: egy CRM/SCM vagy
ERP-alkalmazásnak helye van a mobilokon, például ellátásilánc-menedzsment esetében, a gyártás monitorozása és kontrollja során, vagy a vállalati naptár, vállalati névjegyzék használatakor (Seres, 2009). De említeni lehetne az amerikai Sales Force-rendszert, aminek a fejlesztése eleve webre készült, és komplett CRM-megoldást kínál. Külön ki kell emelni a widget-alkalmazásokat is, amelyek apró és gyors alkalmazások a mobil képernyójére. Itt a rendszerból származó információkat, workflow-kat nyomon lehet követni, beavatkozni, ha szükséges, kiegészítve limitfigyeléssel és riasztással. Az SAP nem akar 100\%-os mobil megoldásokat, nem törekszenek rá, lévén egyes rendszerek nem alkalmasak a mobilon a teljes munkavégzésre (SAP Mobile, 2009).

- Környezetközpontúság. A legtöbb ERP-rendszerben alapvetôen megtalálható valamilyen környezetmenedzsment-megoldás, például az SAP EH\&S program már éles környezetben múködik. Ezek a próbálkozások beváltották a hozzájuk fúzött reményeket, de véleményünk szerint ennél tovább kellene lépni. Ha van egy mindent átfogó vállalatirányítási rendszerünk, azt fel lehetne használni a legkisebb környezetet befolyásoló (károsító) elemtôl egészen a legnagyobbiknak a felügyeletére. A módszertan alapvetően mindegy, egyszerúen azt kell végiggondolni, hogy a cégnek milyen erőforrásai vannak, azokat hogyan alkalmazza, ezáltal mekkora a környezetterhelése. Az egyik alkalmas módszertan a „triple bottom line” lehetne, amit szokás úgy is hívni, ,people, planet, profit”, vagy „economic, social, environmental performance", aminek a legvégén a CSR (corporate social responsibility, vállalati felelősségvállalás) report áll, a fenntarthatósági jelentés. Ezen feldolgozási funkciók hiányoznak még az ERP-rendszerekból. Kifejlesztésükkel automatizálva nem csak statikusan alkalmazná ezt a pozitív, környezetmegóvó gondolkodásmódot. Ha dinamikusan lehetne kontrollálni a folyamatokat, úgy támogathatná a rendszer a vezetốk döntéseit, például olyan kérdések vizsgálatával, hogy egy alkatrész/termék gyártási ciklusa milyen környezeti terheléssel jár (TBL, 2009). Az SAP is a triple bottom line filozófiát alkalmazza, ha nem is ezen a néven nevezi ${ }^{2}$.Véleményünk szerint olyan mélységú elemzéseket is lehetne végezni, mint például, hogy egy adott munkaállomás hány órát van bekapcsolva, és mennyi az üresjárat, mennyit nyomtat, vagy az adott alkatrész beszállítója milyen messze található, és milyen csomagolást használ. Mindezeken az adatokat továbbítja a rendszer a vezetók számára, a saját termináljukra, a pénzügyi és múködési mutatók- 
kal együtt. Olyan környezetirányítási megoldásokat is lehetne kifejleszteni, melyek mögött már szabványok találhatók, például az ISO 14001 vagy az EMAS-szabványok. Egyetlen szabvány vagy rendszer sem ér semmit, ha a mögöttes alkalmazási szándék nincs meg. Alapvetôen három szempont mentén lehet elindulni (ezeknek a zöld informatika adja meg az alapját), mennyi energiát, eróforrást használunk, és ezeket milyen megoldásokkal lehet felügyelni, csökkenteni. A harmadik szempont a hardver- és a szoftvertechnológiára irányul, és nemcsak az új fejlesztéseket, hanem a már múködő alkalmazásokat is érinti. E technológiákat úgy kell kialakítani, áttervezni, hogy elemeik késóbb újra felhasználhatóak legyenek. Az üzleti folyamatokra is érvényesek a fenti elvek. Meg kell vizsgálni, mely elemeket használhatunk fel újra, mely korábbi vállalati folyamat illik az új elgondolásainkba. Legvégül elemezni kell, hogy a kész megoldások megfelelnek-e az előírásoknak, szabványoknak.

- SaaS-szolgáltatások (Software as a Service, szoftver mint szolgáltatás). Egyre inkább elterjedóben van ez a szolgáltatási forma, mely egy komplex megoldás: csak azokért a szolgáltatásokért kell fizetni, amiket használnak, és csak annyi felhasználó után, ahányan igénybe veszik a rendszert. A Gartner jelentései szerint az SaaS-szektor a válság közepette is $18-22 \%$-ban növekedni tudott, ez mindenképpen alátámasztja a múködőképes konstrukció életképességét. Az ajánlott szoftvereken belül a CRM-rendszerek használatában a legjelentôsebb a növekedés (Gartner, 2009). Az ez irányú fejlődésnek gátat szabhat, hogy a nagyvállalatok IT-vezetői egyre inkább mérlegelik, mely információ stratégiai jellegú, és ezért nem adható ki egy SaaS-szolgáltatás keretében. Egy másik statisztika szerint mégis átlagosan 11\%-os emelkedés várható 2011-ig ezen a piacon. Elörejelzésük szerint nem a CRM, hanem az SCM-folyamatok növekednek majd az elsô helyen (Simon és társai, 2007).

- Real time computing. Ez a jövô egyik nagy feladata. A jelenlegi tervek szerint az adatok nem a háttértárakon vannak, hanem a memóriában, és valódi real time módosítást lehet végezni rajtuk. A feldolgozások és kimutatások nem a múltat mutatják, hanem a jelent, valódi adatokkal, pontosan és bárhonnan, akár menet közben egy mobil eszközról lekérve is.

Egy az ERP-rendszerfejlesztésektôl elkülönülő fejlődési irány az egyes feldolgozási tevékenységek centralizálása. Tendenciaként értékelhetók azok a törekvések, melyek bizonyos ügyviteli, adminisztratív jellegú feldolgozásokat (pl. számlázás, bankszámlák kezelése, könyvelés, call center funkció) az országspecifikus rendszerekból kiemelve, a régió egy meghatározott országába telepítik (lásd 4. ábra).

Kutatási eredményeink jelenlegi fázisában, illetve a szakirodalmi felmérésünk alapján kijelenthetô, hogy a globalizált ERP-struktúrák internacionális vállalkozásoknál több irányban fejlődnek, melyek legfontosabb tendenciái a következók:

a) az országszintú, elkülönült ERP-rendszereket egységesítik és a központi feldolgozáshoz integrálják,

b) egyes ERP feldolgozási folyamatok és bizonyos szolgáltatások kezelését a régión belül egységesítik,

c) a korábbi, országonkénti számítóközpontokat összevonják (server parkok kialakítása).

ad. a A világ sok országában jelen lévő cégek gazdasági megfontolások alapján és az áttekinthetőség szempontjából is egyes feldolgozási modulok, illetve a leányvállalatok feldolgozórendszereinek egységesítését határozzák el, sok esetben egy ERP-szállító rendszerére térnek át. Ez a folyamat az évezred elején kezdődött el, és lényeges jegye, hogy a korábbi megoldásokat lépésenként váltják le az új ERPrendszer moduljaival. Több vizsgált esetben az FI-, CO-modulokra való áttéréssel kezdődött a folyamat, ezt követôen a HR-modul bevezetését tervezik (ELTE, 2010; Szabó, 2009a; Kulcsár, 2006).

ad. b Több internacionális cég egy már több éve kialakult gyakorlatot követ az ügyviteli folyamatok szervezésében, melynek lényege az, hogy bizonyos feldolgozásokat a régión belül egy országba központosít. Ezt gazdasági megfontolásból teszi.

ad. c Sok vállalkozás esetén az a hosszabb távú cél, hogy a leányvállalati rendszereket központi helyen, de országspecifikus paraméterezéssel üzemeltessék.

\section{Összefoglalás}

A bevezetésben feltett kérdésekre a kutatási részeredmények alapján már a következók kijelenthetőek:

- Az ERP-rendszerek integrációja átlépte az országszintú vállalatok szintjét, nemzetközivé vált, és a belsố folyamatok integrációja kibővül a vállalaton kívüli, vevố- és szállítóoldali folyamatok integrációjával is. A nemzetközi vállalkozások az egyes országspecifikus ERP-rendszerek egységesítésére törekszenek, és hosszabb távon a központi feldolgozáshoz integrálják. 
- Az ERP-rendszerek globalizálódása a piaci folyamatokhoz közvetlenül kapcsolódó területeken (pl. szállítás, számlázás, partner- és rendelésnyilvántartás) gyorsuló tendenciát mutat.

- Az így kialakuló globalizált ERP-struktúrák modellekbe sorolhatóak, mely modelleket az 1-4. ábrán szemléltetjük.

- A számítástechnikai hardverkapacitásokat is a költségcsökkentés érdekében az internacionális cégen belül centralizálják, vagyis regionális központok alakulnak ki.

A kutatás második fázisában, 2010 szeptemberétől, a részt vevô tanszékek a globalizációs folyamat vizsgálatát a kis- és középvállalkozások (kkv) számára készült ERP-rendszerek, illetve az ezzel összefüggő áttérési motivációk elemzésére szúkítenék. Ezzel szeretnénk a nemzetközi kutatási trendekhez kapcsolódóan az ERP fejlesztési irányokat követni, és az igényeket előre jelezni.

\section{Lábjegyzet}

\section{${ }^{1}$ www.kidrobot.}

${ }^{2}$ http://www.sapsustainabilityreport.com

\section{Felhasznált irodalom}

Amazon (2009): Compiere ERP. Cloud Edition

Ankhen (2009): Supply Chain 2.0 from Aankhen Inc. World Trade. Jul, Vol. 22, Issue 7, p. 59.

Catterfeld, Ch. - Balve, S. (2009): Internationalisierung im Mittelstand - Anforderungen an internationale Lösungen mit lokalem Anspruch. ERP Management Nr. 1/

Clark, L. (2006): Sandvik seeks standard business processes with global ERP roll-out. Computer Weekly; 11/28/2006, p. 18 .

Eggert, S. - Fohrholz, C. (2009): Marktrecherche zum Thema ERP-Internationalisierung. ERP Management 1/2009, p. 52-61.

ELTE (2010): ERP-rendszerek globalizálódása, telepítési struktúrája nemzetközi cégeknél. Kutatási Beszámoló, Budapest, 2010. http://tomx.inf.elte.hu/twiki/pub/Team/ Global/ERP_Kutatasi_Beszamolo_2010_05_10_.pdf

Farid, H. (2009): The Future of ERP

Fulcher, J. (2007): Composite applications framework links ERP and manufacturing operations. Manufacturing Business Technology, Aug, Vol. 25, Issue 8, p. 39.

Gartner (2009): Gartner Says Worldwide SaaS Revenue to Grow 18, Percent in 2009

Gold, L. (2007): SAP charges towards small and midsized market. Accounting Today, 4/2/2007, Vol. 21, Issue 6, p. 20-22.

Gooch-Housego (2008): Hosted solution expands global vision. Works Management, Jan2008, Vol. 61, Issue 1, p. 23.
Gronau, N. (2008): Internationalisierung des Unternehmens mit ERP-Systemen. ERP Management, Nr. 3.

Gunasekaran, A. - Ngai, E. (2007): Knowledge management in 21 st century manufacturing. International Journal of Production Research, 6/1/2007, Vol. 45, Issue 11, p. 2391-2418.

Hess, A. (2009): Speeding up sales. Baseline, Sep2009, Issue 98, p. $36-37$.

Hill, S. (2009): ERP and supply chain: Emerging vendors support global business models. Manufacturing Business Technology, Nov/Dec2009, Vol. 27, Issue 5, p. 19.

Hiraoka, J. (2007): Centralized Microsoft . NET investment, strong service component satisfy 20,000 global ERP users. Manufacturing Business Technology; Jul2007, Vol. 25 Issue 7, p. 28-29.

Hoffman, T. (2007): GLOBAL ERP. Computerworld, 10/15/2007, Vol. 41 Issue 42, p. 36-38.

Höh, H. (2009): Engagement deutscher Unternehmen im Ausland, Statistisches Bundesamt, Wiesbaden STATmagazin

Hughes, R. (2009): Enterprise Social Networking - Don't be afraid, Confenis, Gyôr

ITweb (2009): ERP is recession-proof: A survey shows ERP software is necessary and provides tangible business benefits

Jacobson, S. (2007): Jim Shepherd, Marianne D’Aquila, and Karen Carter, The ERP Market Sizing Report, 20062011, AMR Research

Jutras, C. (2007a): Global ERP advances set stage for manufacturing operations orchestration. Manufacturing Business Technology, May2007, Vol. 25, Issue 5, p. 30-32.

Jutras, C. (2007b): Globalization prompts consideration of automated workflows. Manufacturing Business Technology, Apr2007, Vol. 25 Issue 4, p. 40.

Kidrobot (2009): Kidrobot. Apparel Magazine, May2009, Vol. 50, Issue 9, p. 26-27.

Kulcsár L. (2006): GSAP-Projekt a Shell Hungary Kft.-nél és annak infrastuktúra-vonzata. GDF, diplomamunka 623/2006, Budapest

Malhotra, R. - Temponi, C. (2009): Critical decisions for ERP integration: Small business issues. International Journal of Information Management, 30 (2010) p. 28-37.

Njaa, D. (2008): Project Checkup. Internal Auditor, Aug2008, Vol. 65, Issue 4, p. 31-34.

Qureshi, K.A. - Dawood, M.-uz-Z. (2007): Improving global business economics by seamless business integration framework. Human Systems Management, 2007, Vol. 26, Issue 4, p. 247-255.

SAP (2009a): Adapt and Grow with SAP® Business ByDesign $^{\mathrm{TM}}$

SAP (2009b): The Complete Business Process Outsourcing Cost Picture

SAP (2009c): Knowledge management, SAP Library

SAP Mobile (2009): SAP NetWeaver Mobile, Getting Started Mobile 
Seres S. (2009): Enterprise Mobile Application, Confenis, Gyôr

Szabó Gy. - Kaszai P. (2010): ERP-rendszerek IT-struktúrája multinacionális vállalatoknál. Cikk és konferencia-előadás: Informatika Korszerú Technikái Konferencia, Dunaújváros, 2010. március 5-6.

Szabó Gy. (2009a): ERP-rendszerek bevezetésének lépései, kilenc hazai vállalkozás tapasztalatainak összegzése. Informatika 2009/1., SZÁMALK Kiadó, Budapest

Szabó Gy. (2009b): ERP-rendszerek a gyakorlatban, hazai és nemzetközi megvalósítások elemzése. CONFENIS 2009. Konferencia, Győr. (Előadás és cikk, konferencia kiadvány 88-90. oldal)

Szabó Gy. (2009c): ERP-rendszerek globalizálódása és továbbfejlesztési irányai. Cikk és konferencia-elôadás: Közgazdaságtudományi és Vezetés-vállalkozástudományi Konferencia, Dunaújváros, 2009. november 9-13.

TBL (2009): Triple Bottom Line Magazine
Tóth P. (2008): Az SAP-rendszer pénzügyi és értékesítési moduljának bevezetése a Fabory közép-kelet-európai szervezetében, annak globális gazdasági és informatikai hatásai. GDF 1285/2008

Wailgum, T. (2009a): Millennials + Enterprise Software: Doomed to Fail, CIO Magazine

Wailgum, T. (2009b): Rimini Street Will Now Offer Maintenance Support for SAP's R/3 Products, CIO Magazine

Wheatley, M. (2007): Is the globally integrated enterprise a realistic goal for most manufacturers? Manufacturing Business Technology, Nov2007, Vol. 25, Issue 11, p. 26-28.

Wheatley, M. (2008): Several paths to best practices for SAP ERP users in process industries. Manufacturing Business Technology, Jan2008, Vol. 26, Issue 1, p. 20-22.

Cikk beérkezett: 2010. 4. hó

Lektori vélemény alapján véglegesítve: 2010. 6. hó

\section{E SZÁMUNK SZERZÖI}

Dr. Borbély Szilvia, közgazdász, PhD, MARMOL Research; Dr. Jónás Tamás, egyetemi adjunktus, Budapesti Múszaki és Gazdaságtudományi Egyetem; Dr. Dombi József, egyetemi docens, Szegedi Tudományegyetem; Dr. Tóth Zsuzsanna Eszter, egyetemi adjunktus, Budapesti Múszaki és Gazdaságtudományi Egyetem; Vajda Beáta, tanársegéd, Szegedi Tudományegyetem; Szabó Gyula CSc, foóiskolai docens, Gábor Dénes Főiskola; Bagó Péter, tudományos munkatárs, Pécsi Tudományegyetem; Salamon Melinda, PhD-hallgató, Pécsi Tudományegyetem; Dr. Lehota József, intézetigazgató, egyetemi tanár, Szent István Egyetem 